\title{
The urban green space provision using the standards approach: issues and challenges of its implementation in Malaysia
}

\author{
M. R. Maryanti, H. Khadijah, A. Muhammad Uzair \\ \& M. A. R. Megat Mohd Ghazali \\ Department of Real Estate, Faculty of Geoinformation and Real Estate, \\ Universiti Teknologi Malaysia, Malaysia
}

\begin{abstract}
Standards approach is conventionally used to attain consistency and certainty in urban green space planning. It has been widely used in the United States, Canada, the United Kingdom and Australia since 1920. However, in 1970s, the standards approach received wide criticism and some questioned the relevancy of the approach in high density cities. Most of the local authorities that faced development pressures often failed to achieve the standards due to limited urban spaces and land scarcity. In Malaysia, the National Urbanization Policy has set the standards of 2 hectares per 1000 population by the year 2020. However, due to high urbanization rate and increased densification, some cities, particularly Kuala Lumpur and Penang, are facing difficulties in achieving the target specified in the policy. Therefore, this paper attempts to review the broad literature on the implementation of urban green space provision using the standards approach, the issues and challenges of its implementation in urban green space planning from Malaysian perspectives.

Keywords: planning approach, urban green space provision, standards approach, highly density city, densification, urbanisation.
\end{abstract}

\section{Introduction}

Standards approach has evolved through time and has been used worldwide as one of the conventional methods in providing urban green space. The trajectory of 
standards approach is believed to have begun in the United Kingdom, the pioneer country in adopting the standards approach since the late 1800s [1]. Since then, this approach has become the vital part in urban green space planning policy and delivery to ensure that each citizen has access to the use of urban green space and to fulfil their social needs particularly in a high density urban area. It is known that the provision of an urban green space is essential to improve the quality of life as it offers various benefits in terms of social, environment, economic and aesthetic aspects of urban living and surroundings [2-5]. Thus, the provision of an urban green space is necessary to strengthen the efforts of the local authority to create a liveable city and encourage urban development towards a sustainability framework.

Table 1: $\quad$ The adoption of urban green space standards in several cities [6].

\begin{tabular}{|ll|c|c|c|}
\hline \multicolumn{1}{|c|}{ Cities } & Size & Population & $\mathbf{m}^{2} /$ person \\
\hline 1. & Greater London & 4 hectares & 1000 residents & 40 \\
\hline 2. & Edinburgh & 2.9 hectares & 1000 residents & 29 \\
\hline 3. & Cambridge & 4.6 hectares & 1000 residents & 46 \\
\hline 4. & Washington & 3.8 hectares & 1000 residents & 38 \\
\hline 5. & Minneapolis & 2 hectares & 1000 residents & 20 \\
\hline 6. & Los Angeles & 4.85 hectares & 1000 residents & 48.5 \\
\hline 7. & Kansas City & 3.64 hectares & 1000 residents & 36.4 \\
\hline 8. & Bristol & 1.0 hectares & 1000 residents & 10 \\
\hline 9. & India & 0.8 hectares & 1000 residents & 8 \\
\hline 10. & Pakistan & 0.52 hectares & 1000 residents & 5.2 \\
\hline
\end{tabular}

The application of urban green space standards varied in many cities. Table 1 shows that the application of standards in United Kingdom alone such as Greater London, Edinburg, Cambridge and Bristol has different target size per 1000 populations. What is the basis used to determine such target? According to the World Health Organisation (WHO), every city is recommended to provide a minimum of 9 square metres of urban green space for each person $[7,8]$, provided that it should be accessible [9], safe [10] and functional [11]. WHO also suggest that an ideal amount of urban green space can be generously provided as much as 50 square meters per person [8].

From this viewpoint, a sufficient and generous provision of urban green space especially above the minimum requirement should be the aim of every city in the world. It is imperative because the most liveable city is the one that provide extensive green space for its population [12-14]. Recently, in 2016 Mercer's Quality of Living Survey has voted that Vienna as the most liveable city in the world. Each 1.7 million of its populations has been provided with 120 square metres of urban green space. While Singapore, considered as the third densest city in the world, was able to provide each of its population with 66 square metres of urban green space. Although the city is experiencing rapid development, an increasing number of its population are facing land scarcity issues, the Siemens's Asian Green City Index Report has suggested that Singapore should be a role 
model in spatial planning due to its accomplishment in maintaining urban green space and nature within highly dense and compact urban area [13]. In order to achieve this level, several cities had often practice the standards approach as part of its planning policy and guidelines to ensure that the provision of urban green space is being provided accordingly in concomitant with high densification of urban area or at least more than the minimum amount of urban green space per person, as suggested by WHO.

In Malaysia, the National Urbanization Policy (NUP) has set the standards to achieve 2 hectares per 1000 population by the year 2020. However, due to high urbanization rate and increased densification of the cities, the target seems not possible. To explain this matter in a broad perspective, this article will cover the concept of standards approach, the implementation of standards approach based on Malaysian perspective and the issues and challenges of standards approach in providing urban green space in Malaysia. Until recently, little has been written specifically on standards approach and some of the policy practitioners has questioned and doubted the application of the standards approach. It has also posed dilemma in terms of its implementation among the local authorities in Malaysia. It is hoped that the discussion will contribute for further research to modify and improve the standards approach in accordance to the current and future needs.

\section{The concept of the standards approach}

\subsection{Definition}

Standards approach is conventionally used to provide consistency and certainty in urban green space planning [17]. This approach is a respond to the question of how much green space is enough for a person $[1,21]$. Theobald [1] and Wilkinson [21] shared a similar interpretation that a standards approach is basically a planning concept which is developed by planners to determine how much open space is needed to be provided and what kind of open space should be allocated across a city. It is supposed to be a flexible guideline [21] and supported by several important variables such as user preferences, leisure objectives, recreation experiences, time horizon, economic feasibility, political efficiency and other related elements [22].

\subsection{Types and characteristics}

Globally, there are five types of standards approach that has been commonly used. They are population-ratio, area percentage, catchment area, facility specification and local standards [23] as described in Table 2.

Based on Table 2, population-ratio is the most common type of standards used by the planners in many countries and remains as the major planning criteria for the provision of green space and recreation area [1]. Through the population-ratio, the amount of urban green space per 1000 population or per person is usually fixed by the national or the state planning standards that should be achieved and maintained, no matter how high the rate of densification occurs in the city. The 
Table 2: $\quad$ Types of standards [23].

\begin{tabular}{|ll|l|}
\hline \multicolumn{2}{|c|}{ Types } & \multicolumn{1}{|c|}{ Description } \\
\hline $\begin{array}{l}\text { 1. } \\
\text { Population- } \\
\text { ratio/fixed }\end{array}$ & $\begin{array}{l}\text { A prescribed level of provision of open space related } \\
\text { to the level of population - typically per 1000 } \\
\text { population. }\end{array}$ \\
\hline $\begin{array}{l}\text { 2. } \\
\text { Area percentage } \\
\text { standards }\end{array}$ & $\begin{array}{l}\text { A specified percentage of land to be allocated for } \\
\text { open space (e.g. 10\% from the total development } \\
\text { area is allocated for open space). }\end{array}$ \\
\hline 3. & $\begin{array}{l}\text { Catchment area- } \\
\text { based standards }\end{array}$ & $\begin{array}{l}\text { Distances which residents should have to travel to } \\
\text { gain access (e.g. 1/4 mile walking distance from users } \\
\text { neighbourhood). }\end{array}$ \\
\hline 4. & Facility standards & $\begin{array}{l}\text { Specifications (size, markings and equipment for a } \\
\text { sports field). }\end{array}$ \\
\hline 5. Local standards & $\begin{array}{l}\text { Standards of provision specific to a local area based } \\
\text { on local conditions and data, locally determined or } \\
\text { expressed in any of the above formats. }\end{array}$ \\
\hline
\end{tabular}

amount of urban green space per 1000 population or per person requires the calculation based on its specific formula or a set of rules that is applied uniformly to all situations [17].

There are several reasons why standards which have been developed as guidelines have also been adopted as set of rules [21]. Wilkinson explained that standards approach is clear and simple to assist planners or related agencies to apply them as an instant recommendation or solution to solve problems regarding the adequacy of urban green space provision. Standards are often established by national agency and recognized by experts. Thus this approach is considered to be valid and applicable. The original idea of standards is used as a benchmark among local authorities to evaluate the state or national progress in supplying the urban green space needs for its populations [21].

\section{The implementation of a standards approach in Malaysia}

In Malaysia, the application of standards approach was approved and endorsed by the National Physical Planning Council (NPPC) for the first time in 2005 [24]. The standards of 2 hectares per 1000 populations was set as a target to be achieved by the year of 2020 aligned to the standards of major cities in developed countries such as in Melbourne, New York and Toronto [24]. It is consistent with the National Urbanization Policy (NUP) through Action Plan DPN 9 that stated the provision of open space and recreational area shall be adequately provided according to the needs of the population and the standards requirement of 2 hectares per 1000 population (equivalent to 20 square meters per person) [24].

In order to fulfil the requirement of the standards as stated in the NUP, the provision of urban green space has been implemented mandatorily by the Department of Town and Country Planning (DTCP) Peninsular Malaysia in every development scheme including housing, commercial, industrial, mix 
development, tourism as well as institutional. It became a legal clause to obtain planning permission approval, issued by the local planning authority to the developer in order to carry out the development scheme. According to DTCP, each development scheme shall allocate at least 10 percent of the area as a public open space [25].

In housing scheme, the Planning Standards and Guidelines for Open Space and Recreational Area have clearly stated that the provision of open space shall reach the targeted standards of 2 hectares per 1000 population by the year 2020 . However, the issue arises when planning guidelines is not statutory and local authority is not bound to fully adopt the policy of 10 percent allocation for open space area.

In Malaysia, all land matters are under the exclusive authority of the State Government. It is lawful for the State Government to implement the planning guidelines based on adopt and adapt concept, which allows them to modify the guidelines when they fit and are appropriate to their needs. Once the State Government has established planning guidelines the provision of public open space can be implemented by the Local Authority.

The Local Authority is responsible to execute and enforce the public open space policy within its administrative area. The policy of 10 percent allocation for open space area is a base value set by the Federal Government through the planning guidelines. State Government has different interpretation when they translate the policy according to their condition and needs. Ibrahim et al. reported that the interpretation of the policy differs among local authorities in Peninsular Malaysia [26] (as shown in Table 3).

Based on Table 3, DTCP argued that the policy of 10 percent requirement is difficult to achieve especially in high-density city. Previous researches showed that most of the local authorities that faced development pressures often failed to achieve the standards due to the limited urban space, land scarcity, high rate of densification and urbanization [15, 16, 27]. As the densities and land values increased, it is difficult for most of local authorities or developers to acquire new large areas solely for the purpose of providing urban green space particularly where land is expensive [17].

In Penang for instance, due to its saturated stage, rapid development and the small size of the island has caused to its inability to accommodate the provision of open space on the ground. It is impossible for the developers to meet the policy of 10 percent requirement since the island is facing a critical land shortage and high land value. That is why Penang City Hall has opted to adopt only 4 square metres per unit resident and considered a rooftop garden as an alternative to provide adequate open space in the city.

Thus, due to the inconsistencies in the adoption of 10 percent open space provision among the State Government in Peninsular Malaysia as well as high rate of densification and urbanization of the city, these obstacles may affect the target standards of 2 hectares per 1000 population by the year of 2020, which is less than 4 years to go. These factors explained why some of the policy practitioners doubted and questioned the execution of the standards as well as posing dilemma among the local authorities in Malaysia [24]. 
Table 3: State Government interpretation on the policy of 10 percent allocation for open space areas [26].

\begin{tabular}{|c|c|}
\hline State & Interpretation and enforcement \\
\hline $\begin{array}{ll}\text { 1. } & \text { Negeri } \\
\text { Sembilan }\end{array}$ & Fully adopt 10 percent provision. \\
\hline 2. Kelantan & Fully adopt 10 percent provision. \\
\hline 3. $\quad$ Penang & 4-meter square per resident including high rise scheme. \\
\hline 4. Terengganu & $\begin{array}{l}\text { - } 10 \text { percent of open space allocation for state land; and } \\
\text { - } 5 \text { percent of open space allocation for private land. }\end{array}$ \\
\hline 5. Perlis & $\begin{array}{l}\text { - } 10 \text { percent for housing scheme that develop more than } 4 \\
\text { units. } \\
\text { - } 10 \text { percent ( } 30 \text { percent of the area must be reserved for } \\
\text { public facilities). }\end{array}$ \\
\hline 6. Pahang & $\begin{array}{l}\text { Housing scheme more than } 30 \text { units ( } 3 \text { acres), } 10 \text { percent or } \\
\text { at least } 7 \text { percent must be allocated for open space area. }\end{array}$ \\
\hline 7. Kedah & $\begin{array}{l}\text { Housing scheme of } 0.25 \text { acres or more, } 326.7 \text { square meter } \\
\text { open space per resident must be provided. }\end{array}$ \\
\hline 8. Malacca & $\begin{array}{l}\text { - Housing scheme of } 2 \text { acres or more, } 10 \text { percent of open } \\
\text { space must be provided; or } \\
\text { - Housing scheme less than } 2 \text { acres can opt to provide } 10 \\
\text { percent of open space or based on discretionary of } \\
\text { respective local authority. }\end{array}$ \\
\hline 9. Selangor & $\begin{array}{l}\text { Based on a circular issued by the State Land and Mineral } \\
\text { Office: } \\
\text { - Development scheme more/equal to } 10 \text { acres, } 10 \text { percent } \\
\text { of open space must be provided; } \\
\text { - Development scheme of } 6 \text { to } 10 \text { acres, developer may opt } \\
\text { to provide open space or pay contribution fee to local } \\
\text { authority; } \\
\text { - Development scheme of } 5 \text { acres or less, developer must } \\
\text { pay contribution fee based on following rates: } \\
\text { RM50,000/acres for development scheme within } \\
\text { Klang Valley area; or } \\
\text { RM35,000/acres for development scheme outside } \\
\text { Klang Valley area. }\end{array}$ \\
\hline 10. Perak & $\begin{array}{l}\text { - Fully adopt } 10 \text { percent of open space; } \\
\text { - Development scheme of more than } 5 \text { acres: } \\
\text { - Bungalow and semi-detached housing scheme must } \\
\text { provide at least } 7 \text { percent of open space; while } \\
\text { Low or medium cost housing scheme (including flat) } \\
\text { must provide at least } 10 \text { percent of open space. } \\
\text { - Development scheme of less than } 5 \text { acres: } \\
\text { Bungalow and semi-detached housing scheme, open } \\
\text { space provision is unnecessary; while }\end{array}$ \\
\hline
\end{tabular}


Table 3: Continued.

\begin{tabular}{|c|c|}
\hline State & Interpretation and enforcement \\
\hline 10. Perak & $\begin{array}{l}\text { Low or medium cost housing scheme (including flat) } \\
\text { must provide at least } 5 \text { percent of open space. }\end{array}$ \\
\hline 11. Johor & $\begin{array}{l}\text { - At least } 10 \text { percent of development scheme area must be } \\
\text { allocated for open space provision; } \\
\text { o } 7 \text { percent must be the absolute open space; and } \\
03 \text { percent of the area must be reserved for public } \\
\text { facilities that will be handed over to the state } \\
\text { government. } \\
\text { - Exemption will be given to the application for housing } \\
\text { development of less than } 2 \text { acres and homestead } \\
\text { development; } \\
\text { - For calculating open space area, } 30 \text { percent from public } \\
\text { facilities can be considered as open space. }\end{array}$ \\
\hline
\end{tabular}

\section{The issues and challenges of a standards approach in providing urban green space in Malaysia}

According to NPPC, until December 2009 the total area of open space per person in Malaysia stood at 1.19 hectares and short of 0.81 square meters from the target. But, based on the report by Performance Management and Delivery Unit (PEMANDU), the provision of urban green space per person in Kuala Lumpur has declined from 13 square meters in 2010 to 8.5 square meters in 2014 [28], compared to the amount recorded by NPPC [24]. This issue is alarming and critical as it can contribute to the inadequacy of urban green space provision [28].

From Mazifah and Azahan's point of view [29], to provide urban green space according to the standards, it will require the existing 149 local authorities in Malaysia to provide a minimum area of 112,100 hectares of green space to meet its planning standards. However, the National Landscape Department reported that the total area of current urban green space in Malaysia is only at 13,626 hectares, which is adequate for 6.81 million peoples compared to the actual number of urban population in Malaysia of 15.09 million [30].

It is true that the high urbanization rate has become the main obstacle in preventing the local authorities to achieve the standards. The needs for infrastructure development as well as the demand of urban green space provision grow in parallel and compete with each other for the scarce urban land in order to meet the demand of increasing population as witnessed in Kuala Lumpur and Penang. The expansion of residential, commercial and other spatial infrastructure due to the rapid urbanization has caused the declining of urban green space provision [20]. Urban green space will always force to give way to infrastructure development that seems to be the priority in most of the high-density city $[18,19]$. According to Abdul Mutalib the limited urban space and land scarcity has led to 
the changing need of urban land use status from public to other purposes has also worsened the situation [31]. Thus, the provision of urban green space has become more critical and difficult. This reason was somehow responded to the declination of urban green space quantity and has caused inadequacy of urban green space provision in high-density city [20].

It is a fact that a standards approach focuses more on quantity instead of quality [21]. Based on the Department of Town and Country Planning (DTCP) Peninsular Malaysia, the provision of urban green space in Malaysia is generally at the minimum level [32]. The lack of consideration in the user preferences has caused the design of urban green space based on planning guidelines that occasionally not paralleled to the needs of the current and specific users. Thus, it produces monotonous, bland and plain green spaces that users find it unattractive [17,21]. It happened when most of the developers provide the urban green spaces solely to fulfil the minimum requirements of planning permission approval, omitting the population's needs. Some of the urban green space is found to be located at the unsuitable locations such as on hill slopes, isolated, inaccessible, sharing with other building such as electrical substation, cabin, public hall and water tanks that may interfere user's activities, trigger user's safety as well as affect the percentage of functioned area $[32,33]$. As a result, it neglects the high quality of urban green space that should be delivered to the users.

That is why the standards approach tends to be criticized by many scholars that planners were said to be blindly applying parks standards and fail to respond to the changing demographic patterns, leisure preferences, behaviours, perception, as well as ignoring the requirements of certain group of users especially the elderly, disable and teenagers $[17,21]$. If further actions fail to take place by the related agencies in the near future, the target of the standards as stated in NUP will never be attained and caused the local authority to face inadequacy and poor quality of urban green space provision for urban dwellers in the future.

\section{Conclusions}

This article discussed the issues and challenges of the standards approach in Malaysia based on broad literature. It is found that the implementation of standards approach has created difficulties among local authorities to fulfil the requirement of National Urbanization Policy; to provide open space adequately according to the population needs and requirement of the standards of 2 hectares per 1000 populations. The lack of quality value and inadequacy of quantity of urban green space provision has become the result of adopting the standards approach in Malaysia.

In this situation, CABE Space emphasize that quality is more important than quantity [34]. As for high-density city that faced critical shortage and high land value, it is irrelevant to focus on the achievement of the standards (quantity) and neglect the needs of its population (quality). Further research is necessary to study the needs of the current population living in high-density city and provision of urban green space according to their preferences. It is essential to make sure that the urban green space provided will contribute positively to urban surroundings 
and improve the quality of life of urban dwellers. The importance of examining quality and quantity aspects will enlighten and assist planners in the decisionmaking process and consequently generate a more effective urban green space policy in Malaysia.

\section{References}

[1] Theobald, W. (1984). A history of recreation resource planning: The origins of space standards. Leisure Studies, 3(2), pp. 189-200.

[2] Givoni, B. (1991). Impact of planted areas on urban environmental quality: a review. Atmospheric Environment. Part B. Urban Atmosphere, 25(3), pp. 289-299.

[3] Heidt, V., \& Neef, M. (2008). Benefits of urban green space for improving urban climate. In Ecology, Planning, and Management of Urban Forests (pp. 84-96). Springer New York.

[4] Lee, A. C. K., Jordan, H. C., \& Horsley, J. (2015). Value of urban green spaces in promoting healthy living and wellbeing: prospects for planning. Risk Management and Healthcare Policy, 8, pp. 131-137. http://doi.org/10.2147/RMHP.S61654

[5] Torkildsen, G. (2005). Leisure and recreation management. Psychology Press. From http://samples.sainsburysebooks.co.uk/9781134390083 sample_544268.pdf. Accessed on August 16, 2016.

[6] Khan, A. M. (2012). Planning Standards for Recreational Facilities and Open Space in the Context of Urban Areas of Bangladesh in Khan, A. M. (2014). Revisiting Planning Standards for Recreational Facilities in Urban Areas. Equality in the City: Making Cities Socially Cohesive. World Town Planning Day 2014 from http://www.bip.org.bd/SharingFiles/journal_book /20141118151124.pdf.Accessed on August 2, 2016.

[7] World Health Organization (2010). Urban Planning, Environment and Health: From Evidence to Policy Action. From http://www.euro.who.int/ data/assets/pdf_file/0004/114448/E93987.pdf?ua=1. Accessed on April $\overline{22}, 2016$.

[8] Morar, T., Radoslav, R., Spiridon, L. C., \& Păcurar, L. (2014). Assessing pedestrian accessibility to green space using GIS. Transylvanian Review of Administrative Sciences, 10(42), pp. 116-139.

[9] Takano, T., Nakamura, K., \& Watanabe, M. (2002). Urban residential environments and senior citizens' longevity in megacity areas: the importance of walks able green spaces. Journal of epidemiology and community health, 56(12), pp. 913-918.

[10] Frumkin, H. (2003). Healthy places: exploring the evidence. American journal of public health, 93(9), pp. 1451-1456.

[11] Singh, V. S., Pandey, D. N., \& Chaudhry, P. (2010). Urban forests and open green spaces: Lessons for Jaipur, Rajasthan, India. RSPCB Occasional Paper, 1, pp. 1-23. 
[12] Jim, C. Y., \& Chen, S. S. (2003). Comprehensive green space planning based on landscape ecology principles in compact Nanjing city, China. Landscape and Urban Planning, 65(3), pp. 95-116.

[13] Baharash, Bagherian (2015). Liveable Cities: Greening for Success from https://www.linkedin.com/pulse/liveable-cities-greening-success-baharash -bagherian?trk=pulse-det-nav_art. Accessed on March 20, 2015.

[14] Healthy Parks Healthy People Central (Unspecified). Urban planning and the importance of green space in cities to human and environmental health. From http://www.hphpcentral.com/article/urban-planning-and-theimportance-of-green-space-in-cities-to-human-and-environmental-health. Accessed on July 20, 2016.

[15] Harnik, P. (2000). Inside city parks. Urban Land Institute, Washington, D.C In: Byrne J. and Sipe, N. (2010). Green and open space planning for urban consolidation - A review of the literature and best practice. Urban Research Program, Issues paper 11. p. 13.

[16] Harnik, P., \& Simms, J. (2004). Parks: How far is too far. Planning, 70(11), pp. 8-11.

[17] Byrne J. and Sipe, N. (2010). Green and open space planning for urban consolidation - A review of the literature and best practice. Urban Research Program, Issues paper 11. p. 13.

[18] Mazifah, S., Azahan, A., \& Kadir, A. (2014). Pembangunan bekas tapak pelupusan dan kecukupan penyediaan kawasan lapang: Satu pendekatan menang-menang dalam pembangunan bandar di Malaysia. Geografia: Malaysian Journal of Society and Space, 10(3), pp. 90-100.

[19] Mohd Yusof, M. J. (2013). True colours of urban green spaces: identifying and assessing the qualities of green spaces in Kuala Lumpur, Malaysia. December 2012. Institute of Geography, School of Geosciences, University of Edinburgh, United Kingdom.

[20] Gairola, S., \& Noresah, M. S. (2010). Emerging trend of urban green space research and the implications for safeguarding biodiversity: a viewpoint. Nature and Science, 8(7), pp. 43-49.

[21] Wilkinson, P. F. (1985). The Golden Fleece: The search for standards. Leisure studies, 4(2), pp. 189-203.

[22] Gold, S. M. (1973). Urban recreation planning. Lea and Febiger, Philadelphia In: Wilkinson, P. F. (1985). The Golden Fleece: The search for standards. Leisure studies, 4(2), pp. 189-203.

[23] Veal, A. J. (2013). Open space planning standards in Australia: In search of origins. Australian Planner, 50(3), pp. 224-232.

[24] Department of Town and Country Planning Peninsular Malaysia (2012). Public open space policy: General Assessment from http://smp.townplan. gov.my/?p=4360. Accessed on July 19, 2016.

[25] Department of Town and Country Planning Peninsular Malaysia (2013). Standards and Planning Guideline for Open Space and Recreational Area. Department of Town and Country Planning Peninsular Malaysia. Ministry of Urban Wellbeing, Housing and Local Government, Malaysia. 
[26] Ibrahim, P. H., Dali, M. M., \& Yusoff, S. Y. M. (2013). Implementation of open space: The need for uniform policy. Journal of Sustainable Development, 6(7), 16.

[27] Searle, G. (2009). The fiscal crisis of the local state, urban consolidation and local open space provision in Sydney. In State of Australian Cities Conference, Perth, November (pp. 24-27).

[28] PEMANDU (2014). Economic transformation programme: A roadmap for Malaysia. Department of Prime Minister, Putrajaya from http://etp.pemandu.gov.my/annualreport2014/. Accessed on 28 February 2016.

[29] Mazifah, S. \& Azahan, A. (2014). Ex-landfill Redevelopment and Adequacy of Open Space Provision: An Integrated Approach in Malaysia Urban Development. Developing Country Studies 20(4), pp. 196-201.

[30] National Landscape Department (2012). Directory of public parks in Malaysia. Kuala Lumpur: National Landscape Department.

[31] Abd Mutalib, Jelani (1999). Perancangan Bandar dalam taman. In: Osman Tahir, Mustafa Kamal Mohd Shariff, Norizan Mohamed, Nordin Abd Rahman, Abdul Aziz Othman (Eds) Ke arah Negara Taman: Wawasan dan cabaran. Institut Arkitek Landskap Malaysia, Kuala Lumpur.

[32] Department of Town and Country Planning Peninsular Malaysia (2013). Standards and Planning Guideline for Open Space and Recreational Area. Department of Town and Country Planning Peninsular Malaysia. Ministry of Urban Wellbeing, Housing and Local Government, Malaysia.

[33] Department of Town and Country Planning (2008). Best Planning Practice for Planning and Development in Selangor from http://jpbdselangor.gov. my/Laporan/BuletinRancang/JPBDbuletin2008.pdf. Accessed on July 20, 2016.

[34] CABE Space (2005). Start with the park. Creating sustainable urban green spaces in areas of housing growth and renewal. Commission for Architecture and the Built Environment, London from http://web archive.nationalarchives.gov.uk/20110118095356/http:/www.cabe.org.uk/ files/start-with-the-park.pdf. Accessed on September 22, 2016. 